\title{
Expression of KCNQ1OT1, CDKN1C, H19, and PLAGL1 and the methylation patterns at the KvDMR1 and H19/IGF2 imprinting control regions is conserved between human and bovine
}

\author{
Katherine Marie Robbins, Zhiyuan Chen, Kevin Dale Wells and Rocío Melissa Rivera*
}

\begin{abstract}
Background: Beckwith-Wiedemann syndrome (BWS) is a loss-of-imprinting pediatric overgrowth syndrome. The primary features of BWS include macrosomia, macroglossia, and abdominal wall defects. Secondary features that are frequently observed in BWS patients are hypoglycemia, nevus flammeus, polyhydramnios, visceromegaly, hemihyperplasia, cardiac malformations, and difficulty breathing. BWS is speculated to occur primarily as the result of the misregulation of imprinted genes associated with two clusters on chromosome 11p15.5, namely the KvDMR1 and H19/IGF2. A similar overgrowth phenotype is observed in bovine and ovine as a result of embryo culture. In ruminants this syndrome is known as large offspring syndrome (LOS). The phenotypes associated with LOS are increased birth weight, visceromegaly, skeletal defects, hypoglycemia, polyhydramnios, and breathing difficulties. Even though phenotypic similarities exist between the two syndromes, whether the two syndromes are epigenetically similar is unknown. In this study we use control Bos taurus indicus X Bos taurus taurus F1 hybrid bovine concepti to characterize baseline imprinted gene expression and DNA methylation status of imprinted domains known to be misregulated in BWS. This work is intended to be the first step in a series of experiments aimed at determining if LOS will serve as an appropriate animal model to study BWS.

Results: The use of F1 B. t. indicus $\times$ B. t. taurus tissues provided us with a tool to unequivocally determine imprinted status of the regions of interest in our study. We found that imprinting is conserved between the bovine and human in imprinted genes known to be associated with BWS. KCNQ1OT1 and PLAGL1 were paternally-expressed while CDKN1C and H19 were maternally-expressed in B. t. indicus $\times$ B. t. taurus F1 concepti. We also show that in bovids, differential methylation exists at the KvDMR1 and H19/IGF2 ICRs.
\end{abstract}

Conclusions: Based on these findings we conclude that the imprinted gene expression of KCNQ1OT1, CDKN1C, H19, and PLAGL1 and the methylation patterns at the KvDMR1 and H19/IGF2 ICRs are conserved between human and bovine. Future work will determine if LOS is associated with misregulation at these imprinted loci, similarly to what has been observed for BWS.

Keywords: KvDMR1, H19/IGF2 ICR, KCNQ1OT1, CDKN1C, PLAGL1, Beckwith-Wiedemann syndrome, Methylation, Genomic imprinting, Epigenetics, Bovine

\footnotetext{
* Correspondence: riverarm@missouri.edu

Division of Animal Sciences, University of Missouri, Columbia, MO, USA
} 


\section{Background}

Genomic imprinting is an epigenetic modification that directs parent-specific gene expression. Imprinted genes are responsible for regulating growth and development of the conceptus [1]. These genes are typically found in clusters containing both maternally- and paternallyexpressed genes. The correct allelic expression of the clustered genes is regulated by a neighboring region of DNA which is differentially methylated and is known as the imprinting control region (ICR; [2-4]). The effect of the ICR on a cluster of imprinted genes can span for megabases in a bidirectional manner [5].

Imprinted genes are functionally haploid [6] and therefore are vulnerable to epigenetic mutations and loss-ofimprinting (LOI; [7]). LOI refers to the misregulation of imprinted gene expression which results in either loss of expression or biallelic expression of these genes.

There are several LOI disorders in humans including Beckwith-Wiedemann syndrome (BWS), Angelman syndrome, Prader-Willi syndrome, and Silver Russell syndrome. BWS is the most frequent LOI syndrome observed in humans with an incidence of one in 13,700 live births $[8,9]$. BWS is also the most common pediatric overgrowth syndrome [9]. The overgrowth parameters for height and weight for BWS patients are among the $97^{\text {th }}$ percentile [9].

The primary features of BWS include macroglossia, macrosomia, and abdominal wall defects $[10,11]$. The secondary features include visceromegaly, polyhydramnios, renal abnormalities, facial nevus flammeus, hypoglycemia, hemihyperplasia, ear creases and helical pits, and cardiac malformations [9-12]. Children with this syndrome also have an increased susceptibility (4-21\%) to develop embryonic tumors by the time they turn five years of age $[8,13,14]$. Wilms' tumor of the kidney is the most common embryonic tumor (67\% of cases) observed in BWS patients [14].

BWS is thought to occur because of the dysregulation of several imprinted genes located primarily on chromosome 11p15.5 $[9,11,15]$. The two main imprinted gene clusters associated with BWS are those directed by the KvDMR1 and H19/IGF2 ICRs [12,16]. The BWS-associated imprinted genes regulated by the KvDMR1 include the paternally-expressed non-coding RNA KCNQ1OT1 and the maternally expressed coding genes $C D K N 1 C, K C N Q 1$, and PHLDA2. In mice, expression of CDKN1C is also regulated by a differentially-methylated region (DMR) of DNA that encompasses the promoter and extends through exon $2[17,18]$. Contrary to what has been reported for mice, no differential methylation is observed for CDKN1C in humans [19].

The KvDMR1 is methylated on the maternal allele and unmethylated on the paternal allele in mouse and human. Loss of methylation (LOM) at the KvDMR1 on the maternal allele is the most common epigenetic defect (50\%) observed in BWS patients $[9,12,16,20,21]$. This LOM results in the aberrant expression of the long noncoding RNA (ncRNA) KCNQ1OT1 from the maternal allele which results in bidirectional silencing of the maternally-expressed flanking genes, in particular CDKN1C $[8,22]$.

The H19/IGF2 ICR regulates the expression of the paternally-expressed gene IGF2 and the maternallyexpressed ncRNA H19. This region is unmethylated on the maternal allele and methylated on the paternal allele [12]. The gain of methylation on the maternal allele results in the repression of $\mathrm{H} 19$ from the maternal allele leading to biallelic expression of IGF2. This epimutation occurs in $2-10 \%$ of BWS patients and is highly associated with tumor development $[9,16,23]$. Recent studies have found that some BWS patients also have LOM at the HYMAI/PLAGL1, MEST, and GRB10 ICRs [24-26].

In humans PLAGL1 is found on chromosome six, unlike the other genes associated with BWS which are found primarily on chromosome 11. PLAGL1 functions as a tumor suppressor and can induce apoptosis [27,28]. In a study by Arima et al., [27] it was determined that PLAGL1 is expressed similarly to $C D K N 1 C$ in many tissues. A recent microarray study [29] places PLAGL1 as a pivotal player in the regulation of expression of a network of imprinted genes, including H19, IGF2, and CDKN1C.

In ruminants there is an overgrowth syndrome that resembles BWS. The overgrowth syndrome in ruminants is known as large offspring syndrome (LOS; [30]). LOS has been documented to result from several embryo culture conditions [31-34] and high protein diet supplementation to the dam prior to conception and during early pregnancy [35]. The phenotypical features of LOS include: increased birth weight, macrosomia, skeletal defects, hypoglycemia, polyhydramnios, visceromegaly, difficulty suckling, and perinatal death [30,31,36-38].

Currently, no animal models exist that recapitulate the overgrowth phenotype of BWS. Murine knockout models for BWS have been unable to display all the primary features observed in children with BWS [39]. As an effort to develop treatments for BWS symptoms, our long-term goal is to determine if LOS in ruminants can be used as an animal model to understand the etiology of the LOI syndrome BWS. The goal of this paper was to ascertain baseline allelic expression and DNA methylation in control bovine concepti of imprinted genes/ regions known to be misregulated in BWS. Similar to what has been previously reported $[40,41]$; we show that KCNQ1OT1, H19, CDKN1C and PLAGL1 are imprinted in the bovine. In addition, we confirm that the KvDMR1 and H19/IGF2 ICR are differentially methylated in the bovine genome which is in accordance to what has been reported in humans. Our study extends previous work 
$[40,41]$ in that it provides fixed DNA sequence polymorphisms between Bos taurus indicus and Bos taurus taurus that can be used to distinguish with certainty the parental alleles in F1 individuals.

\section{Methods}

\section{DNA sequence polymorphism identification}

The ability to differentiate between parental alleles in an F1 individual is fundamental when performing genomic imprinting studies. For our studies we used two subspecies of cattle (Bos taurus taurus, Bos taurus indicus), which diverged $\sim 620,000$ years ago [42], to produce F1 individuals. Studies have shown that single nucleotide polymorphisms (SNP) should be found every 172 base pairs (bp) within the exon regions of genes between B. $t$. taurus and B. $t$. indicus [43,44]. Genomic regions sequenced included the exons of KCNQ1OT1, H19, CDKN1C, and PLAGL1 as well as the KvDMR1 and H19/ IGF2 ICRs. Table 1 shows the subspecies-specific single nucleotide polymorphisms (SNPs) for these regions.

\section{Production of Bos taurus indicus $x$ B. taurus taurus day 65 F1 concepti}

All animal work was done in accordance with the University of Missouri Animal Care and Use Committee. The estrous cycles of seven B. $t$. taurus heifers (6 Angus, 1 Hereford) were synchronized using the 14-CIDR ${ }^{\circledR}$-PG (Controlled Intravaginal Drug-Releasing Device and Prostaglandin) estrus synchronization protocol. Briefly, CIDRs were inserted for 14 days to suppress progesterone levels. Sixteen days after the removal of the CIDRs, $25 \mathrm{mg}$ of prostaglandin $\mathrm{F}_{2}$ alpha (Lutalyse; dinoprost tromethamine; Pfizer Animal Health, New York, NY) was administered intramuscularly (i.m.). Three days after prostaglandin injection, $100 \mathrm{mcg}$ of gonadotropin releasing hormone was administered i.m. (Cystorelin; gonadorelin diacetate tetrahydrate; Merial; Duluth, GA). Heifers were then artificially inseminated with semen from one B. $t$. indicus bull (Nelore breed; ABS CSS MR N OB 425/1 677344
29NE0001 97155). Three out of the seven heifers (2 Angus, 1 Hereford) were confirmed pregnant by ultrasonographic examination on day 30 of gestation. Two males and one female $B$. $t$. indicus $\mathrm{x} B$. $t$. taurus F1 concepti were collected on day 65 of gestation at the University of Missouri Veterinary School's abattoir (Figure 1).

Concepti were collected on day 65 because a study by Cezar et al. [45] determined that DNA methylation levels were the same between a day 60 fetus and an adult animal. The following tissues were collected: amnion, chorioallantois, brain, tongue, heart, kidney, liver, lung, intestines, and reproductive tract. Tissues were snap frozen in liquid nitrogen and stored at $-80^{\circ} \mathrm{C}$ until use.

\section{RNA extraction and cDNA synthesis for parental-allelic expression analysis}

The chorioallantois, liver, brain, heart, and tongue of day 65 B. t. indicus $x$ B. t. taurus F1 concepti were homogenized with a plastic disposable pestle (Fischer Scientific; Pittsburgh, PA) in $450 \mu \mathrm{l}$ of lysis binding buffer $(4.5 \mathrm{M}$ guanidine- $\mathrm{HCl}, 50 \mathrm{mM}$ Tris- $\mathrm{HCl}, 30 \%$ Triton $\mathrm{X}-100$ (w/v), $\mathrm{pH}$ 6.6). The tissue lysates were then passed through a 22 and 26 gauge needles connected to a $1 \mathrm{ml}$ syringe. RNA was extracted from the tissues using a commercially available kit (High Pure RNA; Roche Applied Science; Mannheim, Germany) following manufacturer's specifications.

cDNA was synthesized in a $20 \mu \mathrm{l}$ reaction using $10 \mu \mathrm{l}$ of RNA (130 ng Total RNA) and $10 \mu$ l of a master mix containing: $10 \mathrm{mM}$ DTT (Invitrogen; Carlsbad, CA), 1X First Strand buffer (Invitrogen; Carlsbad, CA), $0.5 \mu \mathrm{g}$ random primers (Promega; Madison, WI), 1mM dNTPs (Fischer Scientific; Pittsburgh, PA), 100 units Superscript II reverse transcriptase (RT; Invitrogen; Carlsbad, CA), and 20 units of Optizyme RNase Inhibitor (Fischer Scientific; Pittsburgh, PA). The samples were then incubated in a thermal cycler for one hour at $42^{\circ} \mathrm{C}$ followed by ten minutes at $95^{\circ} \mathrm{C}$. The samples were then stored in the $-20^{\circ} \mathrm{C}$ until further analysis. To verify the absence of DNA contamination, a control was prepared for each

Table 1 DNA sequence polymorphisms used to ascertain allele-specific expression and methylation

\begin{tabular}{|c|c|c|c|c|c|c|}
\hline $\begin{array}{l}\text { Gene/ } \\
\text { ICR Symbol }\end{array}$ & Type of assay & $\begin{array}{c}\text { Maternal } \\
\text { (B.t. taurus) }\end{array}$ & $\begin{array}{c}\text { Paternal } \\
\text { (B.t. indicus) }\end{array}$ & $\begin{array}{l}\text { Location of primers } \\
\text { within the gene }\end{array}$ & $\begin{array}{c}\text { NCBI accession } \\
\text { \# (based on Btau-4.2) }\end{array}$ & $\begin{array}{l}\text { PM location in } \\
\text { reference Btau } 4.2\end{array}$ \\
\hline $\mathrm{H} 19$ & gene expression & C & $\mathrm{T}$ & Exon 2-5 & NR_003958.2 & 1831 \\
\hline$\overline{\text { KCNQ1OT1 }}$ & gene expression & A & G & $\begin{array}{l}\text { Exon } 1 \text { (close to the } \\
\text { start of transaction) }\end{array}$ & NW_001494547.3 & 3146321 \\
\hline CDKN1C & gene expression & C & $\mathrm{T}$ & Exon 2-4 & NW_001494547.3 & 2955801 \\
\hline PLAGL1 & gene expression & $\mathrm{T}$ & G & Exon 6 & NM_001103289.1 & 867 \\
\hline H19/IGF ICR & DNA methylation & A & G & N/A & NW_001494547.3 & 3724402 \\
\hline$\overline{\text { KvDMR1 }}$ & DNA methylation & $\begin{array}{c}\text { G, A, A in/ } \\
\text { del between GA, } C^{* *}\end{array}$ & $\begin{array}{c}\mathrm{C}^{* *}, \mathrm{G}, \mathrm{G}, \text { in/ } \\
\text { del between GA } \\
\text { "GCG", G }\end{array}$ & N/A & NW_001494547.3 & $\begin{array}{c}3134118,3134110, \\
3134095,3134087- \\
3134086,3134072\end{array}$ \\
\hline CDKN1C DMR & DNA methylation & N/A & $\mathrm{N} / \mathrm{A}$ & Exon 1-Intron 2 & NW_001494547.3 & N/A \\
\hline
\end{tabular}

$\mathrm{PM}=$ polymorphisms, $\mathrm{N} / \mathrm{A}=$ not applicable, $\mathrm{C}^{* *}=$ During bisulfite conversion the $\mathrm{C}$ is converted to a $\mathrm{T}$. 

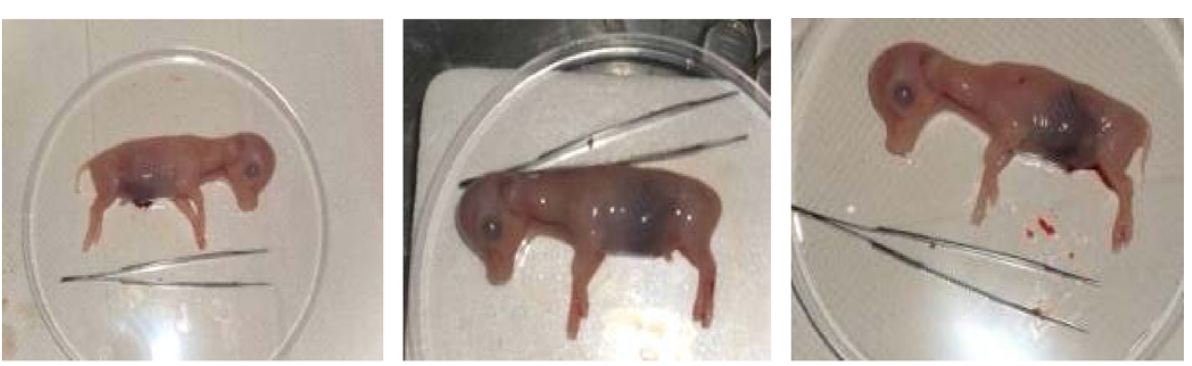

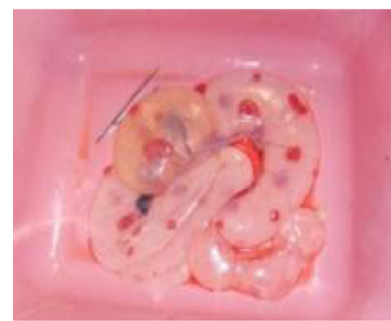

A

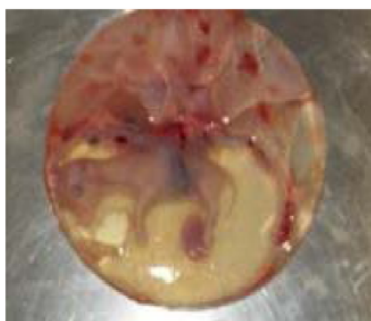

B

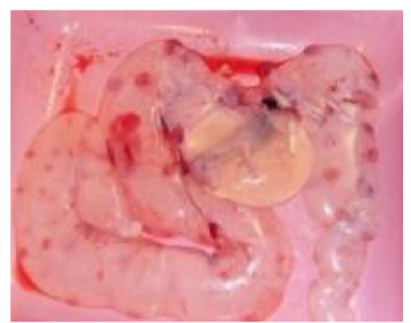

C

Figure 1 Day 65 B. t. indicus $\times$ B. t. taurus F1 concepti. The tissues from these concepti were used to determine baseline imprinted gene expression and DNA methylation in bovine of BWS-associated loci.

sample without Reverse Transcriptase. RNA was also collected and cDNA prepared from several B. t. taurus and $B$. $t$. indicus tissues to serve as restriction fragment length polymorphism (RFLP) assay controls.

\section{Imprinted expression analysis of $B$. $t$. indicus $\mathrm{x}$}

\section{B. t. taurus concepti}

$B$. $t$. indicus $\times$ B. $t$. taurus $\mathrm{F} 1$ tissues were used to determine gene expression of KCNQ1OT1, CDKN1C, H19, and PLAGL1. The PCR primers generated for expression analyses were intron-spanning for $C D K N 1 C$ and $H 19$. However, the primers used to amplify KCNQ1OT1 and PLAGL1 were designed within a single exon. The possibility of DNA contamination in the cDNA was assessed by the exclusion of the Reverse Transcriptase from the cDNA master mix in parallel samples. The conditions used for RT-PCR were modified until a single amplicon was observed for each primer set. The RT-PCR program started with an initial denaturation step at $94^{\circ} \mathrm{C}$ for

Table 2 PCR primers and conditions used determine imprinted gene expression and DNA methylation

\begin{tabular}{|c|c|c|c|c|c|c|c|}
\hline $\begin{array}{l}\text { Gene/ } \\
\text { ICR Symbol }\end{array}$ & & Primers $(5 /-3 /)$ & $\begin{array}{l}\text { PCR Annealiang } \\
\operatorname{Tm}\left({ }^{\circ} \mathrm{C}\right)\end{array}$ & $\begin{array}{l}\text { PCR size } \\
\text { (bp) }\end{array}$ & $\begin{array}{c}\text { Primer [] } \\
\mu \mathrm{M}\end{array}$ & $\begin{array}{l}\mathrm{MgCl}_{2} \\
(9 \mathrm{mM})\end{array}$ & \#Cycles \\
\hline \multirow[t]{2}{*}{$\mathrm{H} 19$} & Forward & GATATGGTCCGGTGTGATGGAGAGAGCA & 62.8 & 752 & 0.3 & 2.5 & 35 \\
\hline & Reverse & TTCGGAGCCTCCAGACTGCGGTG & & & & & \\
\hline \multirow[t]{2}{*}{ KCNQ1OT1 } & Forward & TCGAGGGTACCGGATTCCCAGGC & 64 & 502 & 0.3 & 2.5 & 35 \\
\hline & Reverse & CGCAGGACACCCCAACTACAGCC & & & & & \\
\hline \multirow[t]{2}{*}{ CDKN1C } & Forward & GGAGGCGCCGCGATCAAGAAG & 62 & 745 & 0.3 & 4 & 35 \\
\hline & Reverse & GACAGCGAAAGCGCGAAGAGAC & & & & & \\
\hline \multirow[t]{2}{*}{ PLAGL1 } & Forward & TCAACCGGAAAGACCACCTGAAGA & 60 & 834 & 0.3 & 4 & 35 \\
\hline & Reverse & GGTCAAAGCCTGCATTGAGCTTGT & & & & & \\
\hline \multirow[t]{2}{*}{ H19/IGF2ICR } & Forward & GGGGAGGTTGTCGGGTTTATGG & 60 & 493 & 0.3 & 2.5 & 40 \\
\hline & Reverse & CCGCACCCCTCCTITAACATC & & & & & \\
\hline \multirow[t]{2}{*}{ KvDMR1 } & Forward & $\begin{array}{l}\text { TGAGGAGTGAGTTATGAGGA (taurus) } \\
\text { TGAGGATTGTAGTTGTGAGGA (indicus) }\end{array}$ & 59.2 & $419 / 422$ & 0.3 & 4 & 45 \\
\hline & Reverse & CTACCACATCTACCCCAATC & & & & & \\
\hline \multirow[t]{2}{*}{ CDKN1C DMR } & Forward & GAGGACTGGGCGTTCCACAGGCCA & 62 & 1108 & 0.4 & GC Buffer II Takara & 35 \\
\hline & Reverse & GCCCTTAACGGCCAGGAGGC & & & & & \\
\hline
\end{tabular}

$\mathrm{Tm}=$ Temperature in ${ }^{\circ} \mathrm{C}$, bp $=$ base pairs, []$=$ concentration. 
2:15 min. The denaturation $\left(94^{\circ} \mathrm{C}\right.$ for $\left.30 \mathrm{sec}\right)$, annealing (refer to Table 2), and extension $\left(72^{\circ} \mathrm{C}\right.$ for $\left.1 \mathrm{~min}\right)$ steps were repeated for the specified cycle number on Table 2. The PCR programs ended with a five minute extension at $72^{\circ} \mathrm{C}$. The identity of PCR products was confirmed by restriction enzyme digest or sequencing. No further optimization for sensitivity was required. Primer and PCR condition information may be found in Table 2 .

RFLP was used to identify allelic expression for each gene. The SNPs responsible for restriction site polymorphisms between B. t. taurus and B. t. indicus are shown in Table 2. After restriction enzyme digestion the assays were resolved by polyacrylamide gel electrophoresis (PAGE; Table 3). For cases in which the repressed allele was expressed the band intensity was measured by the UNSCAN-IT gel 5.3 alias gel analysis software (Silk Scientific; Orem, UT) that functions as a gel band densitometer. To be considered biallelic a sample had to have $10 \%$ or higher expression from each parental allele [46].

\section{DNA extraction, bisulfite mutagenesis and COBRA procedures}

DNA was extracted from day 65 B. t. indicus $x$ B. $t$. taurus F1 tissues using a phenol-chloroform extraction procedure. Bisulfite mutagenesis was then performed following the instructions for the Imprint DNA Modification Kit One-Step procedure (Sigma-Aldrich; St. Louis, MO). During the bisulfite mutagenesis procedure all unmethylated cytosines are converted to uracils while methylated cytosines remain cytosines. During PCR the uracils are replaced by thymines. Primers for the bisulfite mutagenized DNA were designed for the H19/IGF2 ICR and the KvDMR1 (Table 2). PCR was used to amplify a 493 bp region of the H19/IGF2 ICR. The amplicon size for the KvDMR1 was 419 bp for the taurus allele and $422 \mathrm{bp}$ for the indicus allele as a result of an insertion/ deletion in the DNA sequence. For the KvDMR1, allelespecific bisulfite primers were designed to amplify each parental allele. The rationale for this was based on the location of the fixed polymorphic sites between the two subspecies of cattle as identified by Sanger sequencing.

Table 3 Restriction enzymes used to determine allele-specific expression of imprinted genes

\begin{tabular}{lccccc}
\hline $\begin{array}{l}\text { Gene } \\
\text { Symbol }\end{array}$ & $\begin{array}{c}\text { Expressed } \\
\text { Allele }\end{array}$ & $\begin{array}{c}\text { Restriction } \\
\text { enzyme }\end{array}$ & $\begin{array}{c}\text { Digested } \\
\text { B t. taurus } \\
\text { (bp) }\end{array}$ & $\begin{array}{c}\text { Digested } \\
\text { B. t. indicus } \\
\text { (bp) }\end{array}$ & $\begin{array}{c}\text { PAGE } \\
\text { Details }\end{array}$ \\
\hline H19 & Maternal & BsiHKAl & 609,143 & $609,35,108$ & $18 \%$ \\
\hline KCNQ10T1 & Paternal & Hinfl & 457,32, & $\begin{array}{c}268,189, \\
13\end{array}$ & 72,13 \\
\hline CDKN1C & Maternal & Avall & 494,251 & 361,251, & $10 \%$ \\
& & & & 133 & \\
\hline PLAGL1 & Paternal & Mlul & 834 & 387,447 & $10 \%$ \\
\hline
\end{tabular}

PAGE $=$ Polyacrylamide gel eclectrophoresis, $b p=$ base pairs.
In order to use the polymorphisms to determine parental-specific methylation primers were required within a region that is $1936 \mathrm{bp}, 67 \%$ GC, flanked by repeat sequences and contains additional polymorphisms. No single primer set was identified that amplified both alleles. Manual design of allele-specific primers allowed for amplification of each KvDMR1 allele separately but in the same reaction. After bisulfite mutagenesis, amplicons from differentially methylated alleles can be recognized by RFLP.

Methylation status of the loci was first determined by combined bisulfite restriction enzyme assay (COBRA). This assay was also used to ascertain that both the methylated and the unmethylated alleles amplified equally with no amplification biased was introduced during PCR. The enzymes used to digest the originally methylated alleles were DpnII and BstUI for the H19/IGF2 ICR and the KvDMR1, respectively. The PCR amplicons and digested products were resolved by $7 \%$ PAGE.

\section{DNA Methylation analysis of the KvDMR1 and H19/IGF2 ICR}

Bisulfite-converted DNA amplicons were isolated from agarose gels using the Wizard SV gel and PCR Clean-Up System (Promega, Madison, WI). H19/IGF2 ICR amplicon was cloned using the pGEM T Easy Vector System ligation buffer protocol (Promega). The plasmid was transformed into chemically competent NEB 5-alpha F' ${ }^{\mathrm{q}}$ E.Coli cells (New England BioLabs; Ipswich, MA) according to the manufacturer's instructions. The KvDMR1 amplicon was cloned using CopyControl PCR cloning kit with TransforMax ${ }^{\mathrm{TM}} \mathrm{EPI}{ }^{\mathrm{Tm}}$ Electrocompe- $^{\mathrm{Tm}}$ tent $E$. coli cells (Epicenter Biotechnologies) according to the manufacturer's specifications except that all the incubation procedures were done at room temperature. Next, the individual clones were sequenced at the University of Missouri's DNA Core using the 96-capillary Applied Biosystems 3730 DNA Analyzer with Big Dye Terminator.

\section{Determination of the methylation status of CDKN1C in bovine}

In the mouse, CDKN1C's DMR has been shown to extend from the promoter region through the second exon. However, the homologous region is not differentially methylated in humans. Many attempts ( $>30$ primer pairs were tested) were made to amplify the promoter of the CDKN1C gene in bovine [NW_001494547.3; 2951474-2953864]. However, sequencing results never coincided with the expected region on chromosome 29 although, according to the databases, the primers aligned perfectly to the bovine CDKN1C's promoter. In addition, even though we were able to sequence $C D K N 1 C$ 's exons 
one and two and intron one, those regions lacked SNPs between $B$. $t$. taurus and B. $t$. indicus. Therefore, we undertook a PCR based methylation analysis to determine if the putative bovine DMR was methylated as in mice or unmethylated as in humans.

Isoschizomers were used to test the methylation status of CDKN1C (HpaII and MspI). These two restriction enzymes allowed differentiation between methylated and unmethylated CpGs. HpaII is methylation sensitive and blocked by CpG methylation and therefore is not be able to cut genomic DNA that is methylated at the CCGG recognition sites. However, MspI is a methylation insensitive restriction enzyme and is able to cleave both methylated and unmethylated DNA at the CCGG recognition sites.

First, genomic DNA was isolated from the kidney of the three day 65 fetuses. The genomic DNA was divided into five groups and treated as follows: 1) untreated DNA, 2) DNA treated with the CpG methyltransferase M. Sss1 (methylates all CpGs), 3) DNA treated with M. Sss1 prior to digestion with HpaII, 4) DNA digested with HpaII, and 5) DNA treated with MspI. All groups were amplified by PCR. The primer pair used (Table 2) amplifies a $1108 \mathrm{bp}$ region encompassing exon one through intron two which contains $19 \mathrm{HpaII} / \mathrm{MspI}$ sites.

\section{Results}

\section{Baseline imprinted gene expression in BWS-associated genes in bovids}

In order to determine if bovids could be used as a model to study BWS we must first determine baseline expression of imprinted genes known to be misregulated with BWS. Three B. t. indicus $x$ B. t. taurus F1 concepti were collected on day 65 of gestation (Figure 1). The brain, tongue, heart, liver, and chorioallantois were analyzed for imprinted gene expression of KCNQ1OT1, CDKN1C, PLAGL1, and H19. In cattle, KCNQ1OT1, CDKN1C, and H19 are located on chromosome 29 while PLAGL1 is found on chromosome 9.

RFLP was the method used to determine allele-specific imprinted gene expression using SNPs identified by our lab (Figure 2). KCNQ1OT1, CDKN1C, PLAGL1, and $H 19$ showed the correct monoallelic expression in all tissues analyzed (Table 4). Nonetheless, gene expression was not detected in every tissue of each F1 conceptus studied (Table 4). For example, the RNA of the chorioallantois that belonged to B. t. indicus $x$ B. t. taurus F1-C appeared to be degraded because no detectable expression was observed for any RNA assay.

Several of the tissues studied had some level expression from the repressed allele of KCNQ1OT1, CDKN1C, PLAGL1, however because this expression was not greater than $10 \%$ they were considered to be expressing

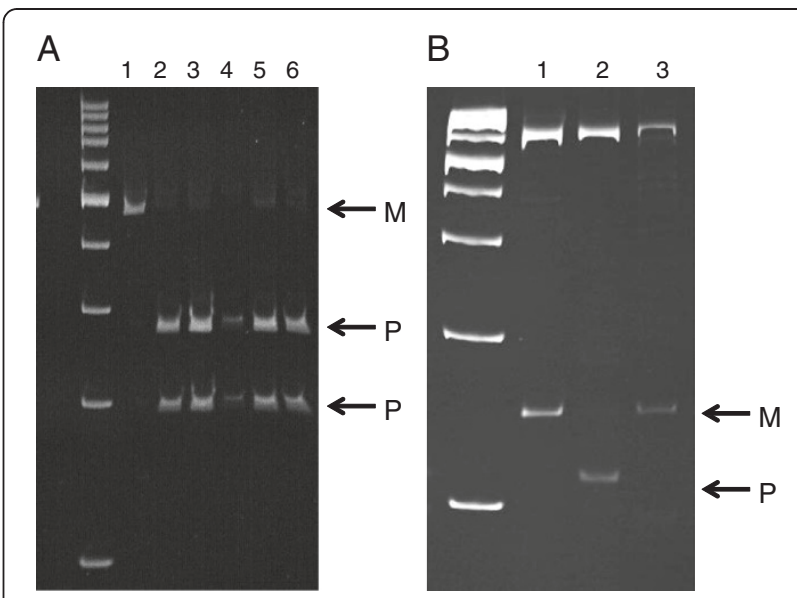

Figure 2 Allele-specific expression of $B$. $t$. indicus $\times$ B. $t$. taurus F1 concepti. Shown are two examples of the RFLP assay used to distinguish parent-specific gene expression in B. t. indicus $\mathrm{x}$

B. t. taurus F1concepti. DNA sequence polymorphisms between B. t. indicus and B. t. taurus were used as a diagnostic test to identify the parental allele origin of the transcript. A. KCNQ1OT1 (paternally-expressed gene). Lanes = 1: B. t. taurus liver; 2: B. t. indicus kidney, 3: B. t. indicus fat; 4: F1B heart, 5: F1B liver; 6: F1C heart. B. H19 (maternally-expressed gene). Lanes $=1:$ B. t. taurus muscle; 2 : B. t. indicus fat; 3: F1A heart. $M=$ maternal allele, $P=$ paternal allele.

those genes in a monoallelic manner. We amplified and digested B. t. taurus and B. t. indicus to serve as controls for restriction enzyme digestion patterns and to differentiate between leaky expression of the repressed alleles and incomplete restriction enzyme digestion of the

Table 4 BWS-associated imprinted gene expression in B. t. indicus $\times$ B. t. taurus F1

\begin{tabular}{|c|c|c|c|c|}
\hline Tissue & KCNQ10T1 & $\mathrm{H} 19$ & CDKN1C & PLAGL1 \\
\hline Conceptus A & \multicolumn{4}{|c|}{ (\%)- expression from repressed allele } \\
\hline Chorioallantois & Mono (2.65\%) & Mono (0\%) & Mono (0\%) & Mono (3.75\%) \\
\hline Liver & Mono (6.90\%) & Mono (0\%) & Mono (0\%) & Mono (4.73\%) \\
\hline Brain & Mono (6.01\%) & Mono (0\%) & Mono (0\%) & Mono $(1.66 \%)$ \\
\hline Heart & $\mathrm{N} / \mathrm{A}$ & Mono (0\%) & Mono (0\%) & Mono $(2.17 \%)$ \\
\hline Tongue & Mono (4.09\%) & Mono (0\%) & Mono (0\%) & Mono $(6.39 \%)$ \\
\hline \multicolumn{5}{|l|}{ Conceptus B } \\
\hline Chorioallantois & Mono (2.33\%) & Mono (0\%) & Mono (0\%) & Mono $(5.50 \%)$ \\
\hline$\underline{\text { Liver }}$ & Mono (6.17\%) & Mono (0\%) & Mono (0\%) & $\mathrm{N} / \mathrm{A}$ \\
\hline Brain & Mono $6.46 \%$ & Mono (0\%) & Mono (0\%) & Mono (2.63\%) \\
\hline Heart & Mono (8.01\%) & Mono (0\%) & Mono (0\%) & Mono (4.59\%) \\
\hline Tongue & Mono (7.08\%) & Mono (0\%) & Mono (0\%) & Mono $(9.58 \%)$ \\
\hline \multicolumn{5}{|l|}{ Conceptus C } \\
\hline Chorioallantois & $\mathrm{N} / \mathrm{A}$ & $\mathrm{N} / \mathrm{A}$ & $\mathrm{N} / \mathrm{A}$ & $\mathrm{N} / \mathrm{A}$ \\
\hline Liver & Mono (4.01\%) & Mono (0\%) & Mono (0\%) & Mono (2.40\%) \\
\hline Brain & Mono (5.60\%) & Mono (0\%) & Mono (0\%) & Mono (4.77\%) \\
\hline Heart & Mono (9.74\%) & Mono (0\%) & Mono (0\%) & Mono (5.74\%) \\
\hline Tongue & Mono (1.96\%) & Mono (0\%) & Mono (0\%) & Mono (0\%) \\
\hline
\end{tabular}

Imprinted Gene expression analyzed by RFLP. Mono= monoallelic expression. 
tissues. Repression of the paternally-inherited allele of H19 appeared complete.

Baseline methylation in BWS-associated imprinting control regions in bovids

COBRA (data not shown) and Bisulfite sequencing were used to determine the methylation status of the H19/ IGF2 ICR (Figure 3) and the KvDMR1 (Figure 4). These two ICRs are the two differentially methylated regions primarily misregulated in BWS patients [9]. From our study we were able to determine that differential methylation is observed within these ICRs in control B.t. indicus $x$ B. t. taurus F1 concepti. Both the KvDMR1 and the H19/IGF2 regions in the bovine showed differential

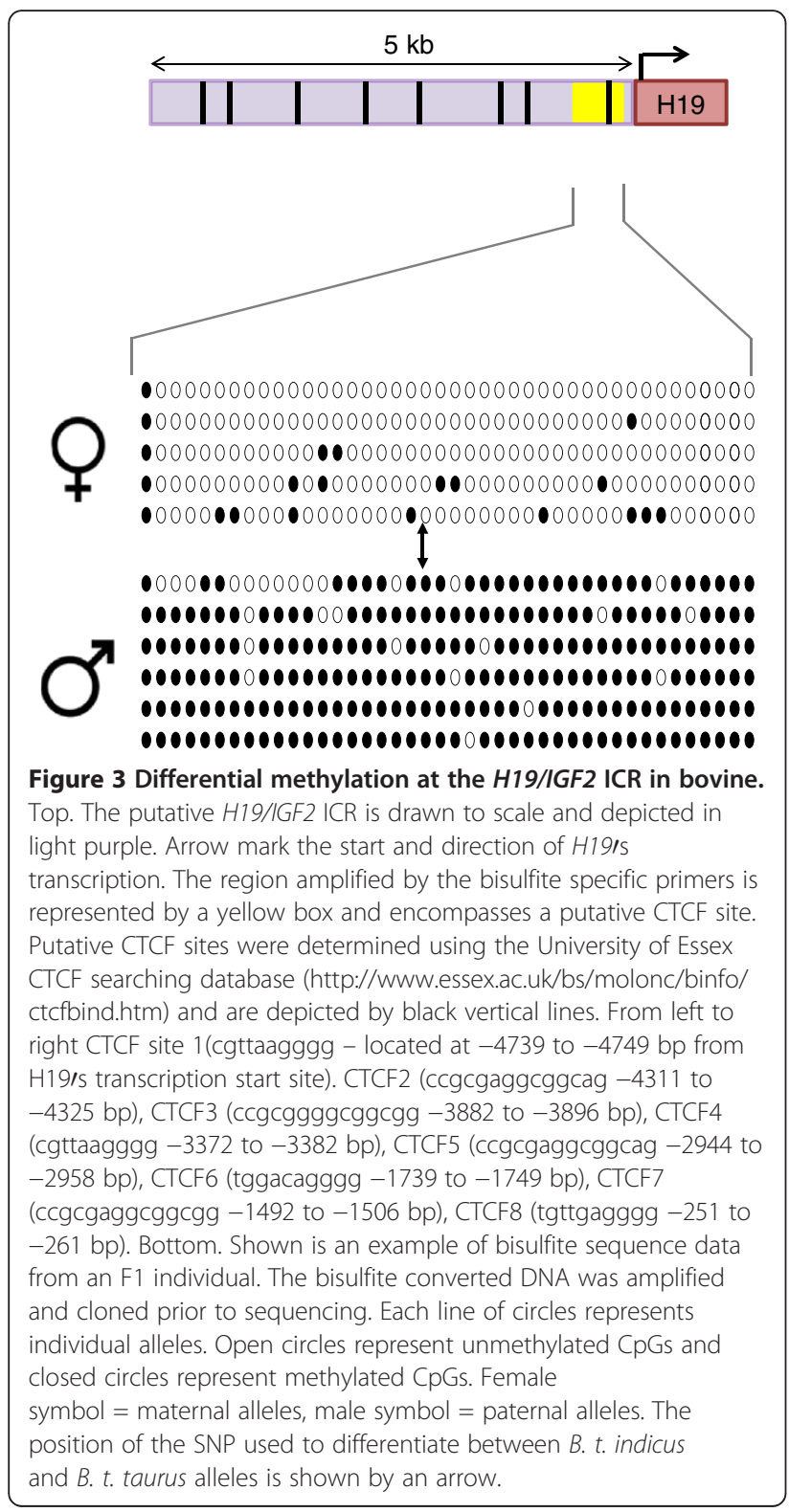

methylation between the parental alleles similar to what has been observed in humans [47-50].

Methylation analysis of CDKN1C's putative DMR in bovids The PCR primers were able to amplify a region of the correct size for the untreated genomic DNA, the M. Sss1 treated DNA, and the M. Sss1 + HpaII treated DNA groups. As expected, MspI digestion cleaved the DNA thus fragmenting the template and preventing amplification of the region (Figure 5). No amplicons were detected for the genomic DNA treated with HpaII suggesting at least one hypomethylated $\mathrm{CpG}$ in this genomic region.

\section{Discussion}

In this study, we set out to determine the pattern of expression in bovids of four imprinted genes associated with the human overgrowth syndrome Beckwith-Wiedemann. We analyzed gene expression and DNA methylation in embryonic and extraembryonic tissues of three day 65 B. t. indicus $\times$ B. t. taurus $\mathrm{F} 1$ concepti. By using RT-PCR and RFLP analysis we were able to determine

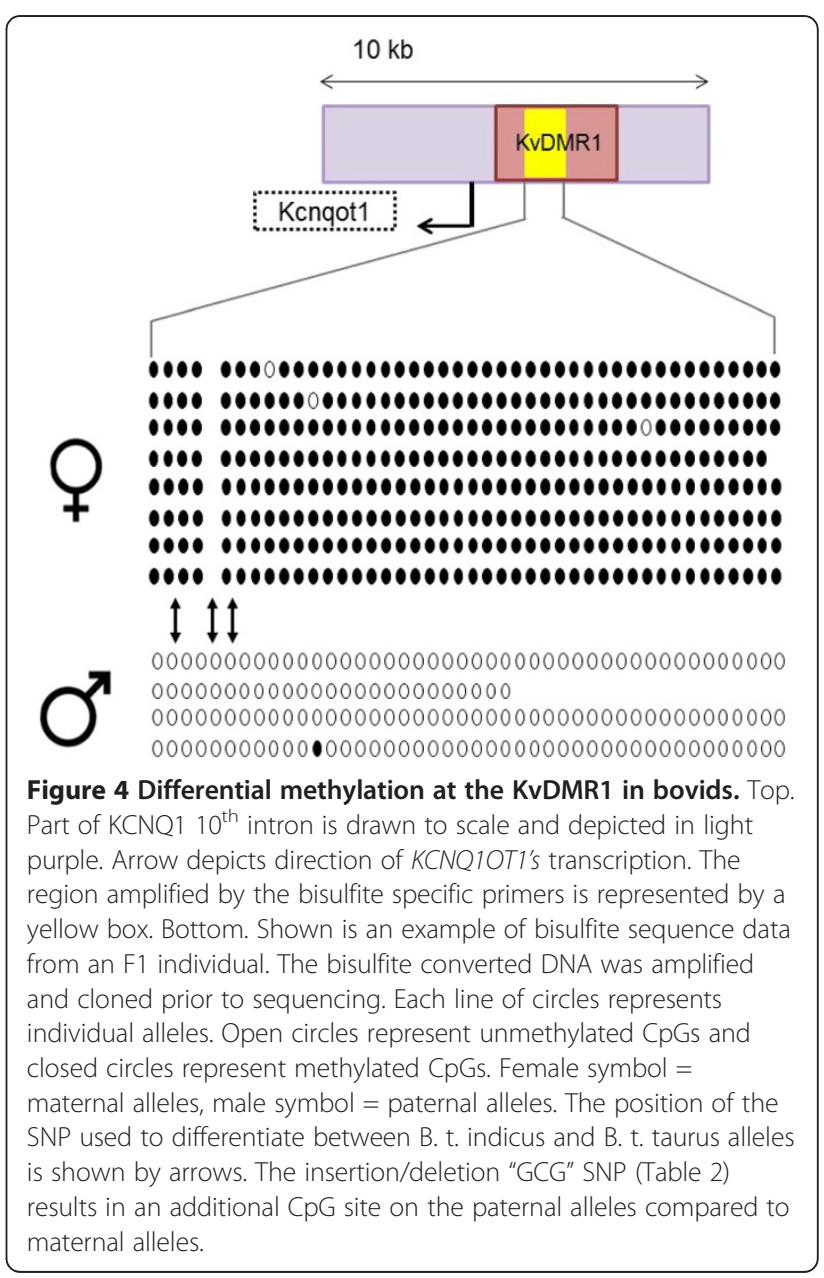




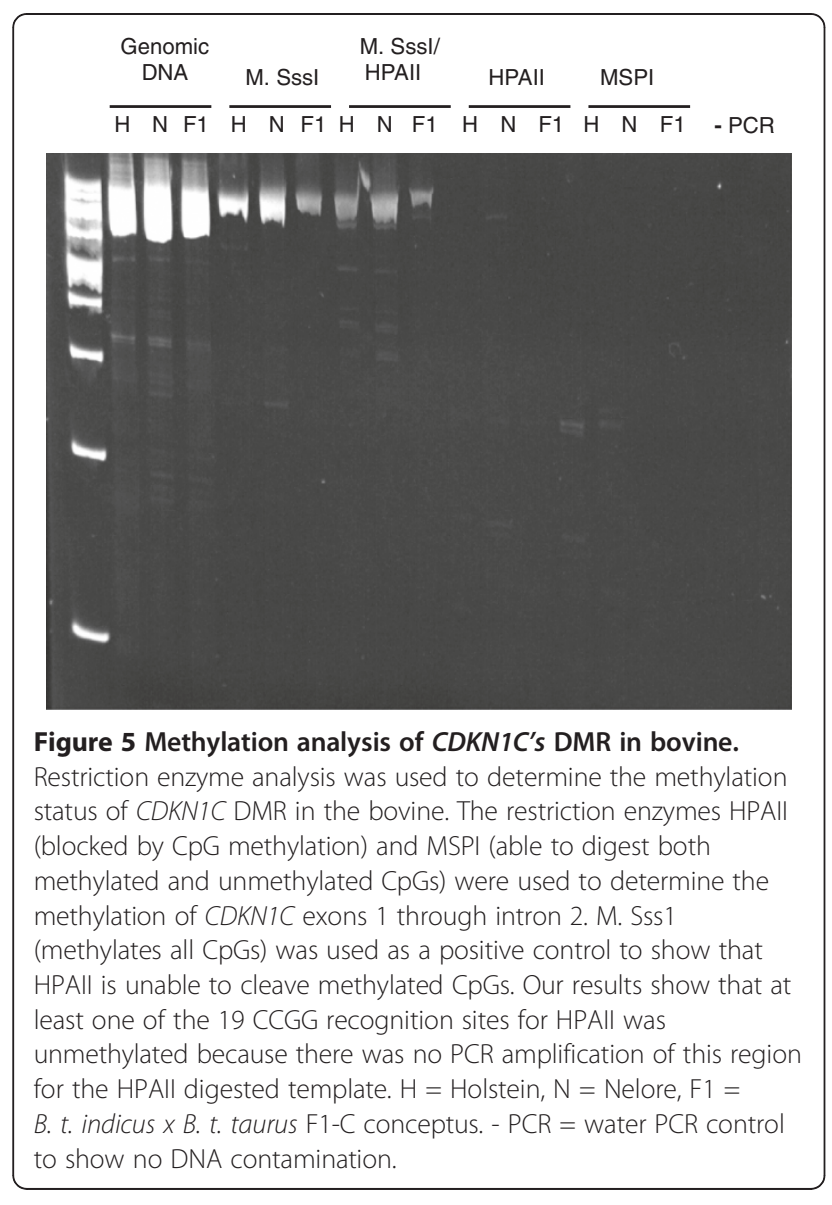

the imprinted gene expression for KCNQ1OT1, PLAGL1, $C D K N 1 C$, and H19. Our results showed that similar to humans, KCNQ1OT1 and PLAGL1 are monoallelically expressed from the paternal allele while CDKN1C and $H 19$ are maternally-expressed genes. The imprinted gene expression was observed in all tissues analyzed which included brain, heart, liver, tongue, and chorioallantois.

Another result from this study confirmed recent observations [40] that the KvDMR1 and the H19/IGF2 ICRs are differentially methylated in cattle as has been reported for human and mouse. Our results add to the current knowledge because of our ability to unequivocally assign methylation status of these ICRs to each parental allele based on the identified SNPs. Results from this work suggest that the CDKN1C's promoter is hypomethylated in bovine as it is in human. This is in accordance with Hori et al. [40] who has recently reported a hypomethylated state of the aforementioned promoter.

The imprinted genes associated with BWS have been shown to be conserved between the human and mouse [51-56]. However, there have been several mouse models which have not been able to recapitulate all the diagnostic clinical features associated with BWS [39,57]. No current animal models are able to fully phenocopy BWS. This fact is important for investigators with the goal treating BWS symptoms.

There are many reasons to propose the use of bovids as a model to study BWS. First, LOS has several phenotypical similarities with BWS [30,31,33,37,38]. Second, increased IGF2 expression has been observed in day 70 LOS concepti [32]. This is of relevance since $2-10 \%$ of BWS patients have biallelic expression of the paternally-expressed IGF2 in tongue and in fibroblast [58]. In BWS, IGF2's biallelic expression is due to gain of methylation on the paternal allele at the H19/IGF2 ICR. Third, the parent-specific expression pattern of several imprinted genes in the mouse is not conserved in humans (i.e. Gatm, Dcn, and IGF2r; [59-63]). Fourth, comparative genome analyses $[64,65]$ show that the percent identity between the genomes of cattle and human is $73.8 \%$ while the percent identity between the mouse and human genomes is $66.8 \%$ [66]. In addition, pairwise alignments with the human genome of putative transcriptional regulatory regions show a higher homology for cow than for mouse ( $\sim 80 \%$ vs. $~ 70 \%$ [66]). Fifth, as expected given the genomic similarity between human and bovine, we show here that there is conservation of expression and methylation patterns at the BWS-associated loci. Sixth, both species have a nine month gestation period. This is relevant because the sequence of events that result in a condition may occur at similar times during pregnancy. Seventh, both the bovine and human gestation usually involves one offspring. It is likely that there has been divergence for growth regulation of the conceptus between litter bearing and non-litter bearing species.

Another important similarity between humans and ruminants is the adverse response of preimplantation embryos to in vitro manipulations. For instance, children that are conceived by the use of assisted reproductive technologies have a higher incidence (3-9 times) of having the LOI overgrowth syndrome BWS [23,26,48,67-70]. Likewise, a fetal overgrowth syndrome has also been documented in ruminants as a result of ART. In ruminants this syndrome is known as LOS. Since the overgrowth phenotype has been observed in ruminants and humans as a result of assisted reproduction, we [71] and others [40] have proposed that both syndromes have similar epigenetic etiologies. In order to determine the plausibility of our hypothesis we need to ascertain if all BWSassociated imprinted gene expression misregulation is recapitulated in LOS. Ongoing studies from our laboratory are determining if LOS and BWS are epigenetically similar.

\section{Conclusion}

In conclusion, our study established the imprinting status of KCNQ1OT1, CDKN1C, PLAGL1, and H19 in bovine day 65 B. t. indicus $\times$ B. t. taurus F1concepti and 
found that imprinting was conserved with humans. These genes are associated with the human overgrowth and loss-of-imprinting syndrome BWS. We have also determined that the ICRs primarily affected in BWS, namely KVDMR1 and H19/IGF2, are differentially methylated in bovids as in humans. Currently no animal models are able to fully recapitulate BWS. Our results suggest that bovids may be able to serve as an appropriate animal model for studying BWS.

\section{Competing interests}

The authors declare that they have no competing interests

\section{Authors' contributions}

KMR - performed the majority of the work presented in this manuscript and drafted the manuscript. ZC - optimized the PCR conditions used to amplify the KVDMR1 and analyzed allele-specific methylation of the KVDMR1. KDW assisted with genome sequence alignments to identify the imprinted loci in the bovine genome and finalized the manuscript. RMR - conceived and designed the project and finalized the manuscript. All authors read and approved the final manuscript.

\section{Acknowledgments}

We would like to acknowledge Dr. Michael Smith, Ms. Emma Jinks, and Mr. Ky Pohler for their invaluable assistance with the production of the $B . t$. indicus $x$ B. t. taurus day 65 F1 concepti. We want to thank Mr. Jordan Thomas for assistance with isolation of plasmid DNA and Mr. Chad O'Gorman for assistance with optimization of PCR conditions. In addition, we need to thank Mr. Brian Brace from ABS Global for B. t. indicus semen donation. This work was supported by the Reproductive Biology Group Food for the $21^{\text {st }}$ Century program at the University of Missouri, The University of Missouri Research Board (grant number - CB000384) and National Institutes of Health (grant number - 5R21HD062920-02).

Received: 8 August 2012 Accepted: 6 November 2012 Published: 15 November 2012

\section{References}

1. Reik W, Walter J: Genomic imprinting: parental influence on the genome. Nat Rev Genet 2001, 2(1):21-32.

2. Verona RI, Mann MR, Bartolomei MS: Genomic imprinting: intricacies of epigenetic regulation in clusters. Annu Rev Cell Dev Biol 2003, 19:237-259.

3. Zhang Y, Qu L: Non-coding RNAs and the acquisition of genomic imprinting in mammals. Sci China C Life Sci 2009, 52(3):195-204.

4. Lewis A, Reik W: How imprinting centres work. Cytogenet Genome Res 2006, 113(1-4):81-89.

5. Pandey RR, Mondal T, Mohammad F, Enroth S, Redrup L, Komorowski J, Nagano T, Mancini-Dinardo D, Kanduri C: Kcnq1ot1 antisense noncoding RNA mediates lineage-specific transcriptional silencing through chromatin-level regulation. Mol Cell 2008, 32(2):232-246.

6. Fowden AL, Coan PM, Angiolini E, Burton GJ, Constancia M: Imprinted genes and the epigenetic regulation of placental phenotype. Prog Biophys Mol Biol 2011, 106(1):281-288.

7. Cui H, Cruz-Correa M, Giardiello FM, Hutcheon DF, Kafonek DR, Brandenburg S, Wu Y, He X, Powe NR, Feinberg AP: Loss of IGF2 imprinting: a potential marker of colorectal cancer risk. Science 2003, 299(5613):1753-1755.

8. Choufani S, Shuman C, Weksberg R: Beckwith-Wiedemann syndrome. Am J Med Genet C Semin Med Genet 2010, 154C(3):343-354.

9. Weksberg R, Shuman C, Beckwith JB: Beckwith-Wiedemann syndrome. Eur J Hum Genet 2010, 18(1):8-14.

10. Elliott M, Maher ER: Beckwith-Wiedemann syndrome. J Med Genet 1994, 31(7):560-564

11. Cooper WN, Luharia A, Evans GA, Raza H, Haire AC, Grundy R, Bowdin SC, Riccio A, Sebastio G, Bliek J, et al: Molecular subtypes and phenotypic expression of Beckwith-Wiedemann syndrome. Eur J Hum Genet 2005, 13(9):1025-1032.
12. Weksberg R, Smith AC, Squire J, Sadowski P: Beckwith-Wiedemann syndrome demonstrates a role for epigenetic control of normal development. Hum Mol Genet 2003, 12 (Spec No 1):R61-R68.

13. Weksberg R, Shuman C, Caluseriu O, Smith AC, Fei YL, Nishikawa J, Stockley $\mathrm{TL}$, Best L, Chitayat D, Olney A, et al: Discordant KCNQ1OT1 imprinting in sets of monozygotic twins discordant for Beckwith-Wiedemann syndrome. Hum Mol Genet 2002, 11(11):1317-1325.

14. Rump P, Zeegers MP, Van Essen AJ: Tumor risk in Beckwith-Wiedemann syndrome: A review and meta-analysis. Am J Med Genet A 2005, 136(1):95-104.

15. Manipalviratn S, DeCherney A, Segars J: Imprinting disorders and assisted reproductive technology. Fertil Steril 2009, 91(2):305-315.

16. Sparago A, Russo S, Cerrato F, Ferraiuolo S, Castorina P, Selicorni A, Schwienbacher C, Negrini M, Ferrero GB, Silengo MC, et al: Mechanisms causing imprinting defects in familial Beckwith-Wiedemann syndrome with Wilms' tumour. Hum Mol Genet 2007, 16(3):254-264.

17. Bhogal B, Arnaudo A, Dymkowski A, Best A, Davis TL: Methylation at mouse Cdkn1c is acquired during postimplantation development and functions to maintain imprinted expression. Genomics 2004, 84(6):961-970.

18. Cerrato F, Sparago A, Di Matteo I, Zou X, Dean W, Sasaki H, Smith P, Genesio R, Bruggemann M, Reik W, et al: The two-domain hypothesis in Beckwith-Wiedemann syndrome: autonomous imprinting of the telomeric domain of the distal chromosome 7 cluster. Hum Mol Genet 2005, 14(4):503-511.

19. Chung WY, Yuan L, Feng L, Hensle T, Tycko B: Chromosome 11p15.5 regional imprinting: comparative analysis of KIP2 and $\mathrm{H} 19$ in human tissues and Wilms' tumors. Hum Mol Genet 1996, 5(8):1101-1108.

20. Lee MP, DeBaun MR, Mitsuya K, Galonek HL, Brandenburg S, Oshimura M, Feinberg AP: Loss of imprinting of a paternally expressed transcript, with antisense orientation to KVLQT1, occurs frequently in BeckwithWiedemann syndrome and is independent of insulin-like growth factor II imprinting. Proc Natl Acad Sci USA 1999, 96(9):5203-5208.

21. Mitsuya K, Meguro M, Lee MP, Katoh M, Schulz TC, Kugoh H, Yoshida MA, Niikawa N, Feinberg AP, Oshimura M: LIT1, an imprinted antisense RNA in the human KvLQT1 locus identified by screening for differentially expressed transcripts using monochromosomal hybrids. Hum Mol Genet 1999, 8(7):1209-1217.

22. Horike S, Mitsuya K, Meguro M, Kotobuki N, Kashiwagi A, Notsu T, Schulz TC, Shirayoshi Y, Oshimura M: Targeted disruption of the human LIT1 locus defines a putative imprinting control element playing an essential role in Beckwith-Wiedemann syndrome. Hum Mol Genet 2000, 9(14):2075-2083.

23. DeBaun MR, Niemitz EL, Feinberg AP: Association of in vitro fertilization with Beckwith-Wiedemann syndrome and epigenetic alterations of LIT1 and H19. Am J Hum Genet 2003, 72(1):156-160.

24. Rossignol S, Steunou V, Chalas C, Kerjean A, Rigolet M, Viegas-Pequignot E, Jouannet $P$, Le Bouc $Y$, Gicquel $C$ : The epigenetic imprinting defect of patients with Beckwith-Wiedemann syndrome born after assisted reproductive technology is not restricted to the $11 \mathrm{p} 15$ region. J Med Genet 2006, 43(12):902-907.

25. Bliek J, Verde G, Callaway J, Maas SM, De Crescenzo A, Sparago A, Cerrato F, Russo S, Ferraiuolo S, Rinaldi MM, et al: Hypomethylation at multiple maternally methylated imprinted regions including PLAGL1 and GNAS loci in Beckwith-Wiedemann syndrome. Eur J Hum Genet 2009, 17(5):611-619.

26. Lim D, Bowdin SC, Tee L, Kirby GA, Blair E, Fryer A, Lam W, Oley C, Cole T, Brueton LA, et al: Clinical and molecular genetic features of Beckwith-Wiedemann syndrome associated with assisted reproductive technologies. Hum Reprod 2009, 24(3):741-747.

27. Arima T, Kamikihara T, Hayashida T, Kato K, Inoue T, Shirayoshi Y, Oshimura M, Soejima H, Mukai T, Wake N: ZAC, LIT1 (KCNQ1OT1) and p57KIP2 (CDKN1C) are in an imprinted gene network that may play a role in Beckwith-Wiedemann syndrome. Nucleic Acids Res 2005, 33(8):2650-2660.

28. Valleley EM, Cordery SF, Bonthron DT: Tissue-specific imprinting of the ZAC/PLAGL1 tumour suppressor gene results from variable utilization of monoallelic and biallelic promoters. Hum Mol Genet 2007, 16(8):972-981.

29. Varrault A, Gueydan C, Delalbre A, Bellmann A, Houssami S, Aknin C, Severac D, Chotard L, Kahli M, Le Digarcher A, et al: Zac1 regulates an imprinted gene network critically involved in the control of embryonic growth. Dev Cell 2006, 11(5):711-722.

30. Young LE, Sinclair KD, Wilmut I: Large offspring syndrome in cattle and sheep. Rev Reprod 1998, 3(3):155-163. 
31. Farin PW, Farin CE: Transfer of bovine embryos produced in vivo or in vitro: survival and fetal development. Biol Reprod 1995, 52(3):676-682.

32. Blondin P, Farin PW, Crosier AE, Alexander JE, Farin CE: In vitro production of embryos alters levels of insulin-like growth factor-II messenger ribonucleic acid in bovine fetuses 63 days after transfer. Biol Reprod 2000, 62(2):384-389.

33. Bertolini $M$, Anderson GB: The placenta as a contributor to production of large calves. Theriogenology 2002, 57(1):181-187.

34. Lazzari G, Wrenzycki C, Herrmann D, Duchi R, Kruip T, Niemann H, Galli C: Cellular and molecular deviations in bovine in vitro-produced embryos are related to the large offspring syndrome. Biol Reprod 2002, 67(3):767-775.

35. McEvoy TG, Robinson JJ, Aitken RP, Findlay PA, Robertson IS: Dietary excesses of urea influence the viability and metabolism of preimplantation sheep embryos and may affect fetal growth among survivors. Anim Reprod Sci 1997, 47(1-2):71-90.

36. Sangild PT, Schmidt M, Jacobsen H, Fowden AL, Forhead A, Avery B, Greve T: Blood chemistry, nutrient metabolism, and organ weights in fetal and newborn calves derived from in vitro-produced bovine embryos. Biol Reprod 2000, 62(6):1495-1504

37. Hiendleder S, Mund C, Reichenbach HD, Wenigerkind H, Brem G, Zakhartchenko $\mathrm{V}$, Lyko F, Wolf E: Tissue-specific elevated genomic cytosine methylation levels are associated with an overgrowth phenotype of bovine fetuses derived by in vitro techniques. Biol Reprod 2004, 71(1):217-223.

38. Farin PW, Piedrahita JA, Farin CE: Errors in development of fetuses and placentas from in vitro-produced bovine embryos. Theriogenology 2006, 65(1):178-191.

39. Leighton PA, Ingram RS, Eggenschwiler J, Efstratiadis A, Tilghman SM: Disruption of imprinting caused by deletion of the $\mathrm{H} 19$ gene region in mice. Nature 1995, 375(6526):34-39.

40. Hori N, Nagai M, Hirayama M, Hirai T, Matsuda K, Hayashi M, Tanaka T, Ozawa T, Horike S: Aberrant CpG methylation of the imprinting control region KvDMR1 detected in assisted reproductive technology-produced calves and pathogenesis of large offspring syndrome. Anim Reprod Sci 2010, 122(3-4):303312 .

41. Couldrey C, Lee RS: DNA methylation patterns in tissues from mid-gestation bovine foetuses produced by somatic cell nuclear transfer show subtle abnormalities in nuclear reprogramming. BMC Dev Biol 2010, 10:27.

42. MacHugh DE, Shriver MD, Loftus RT, Cunningham P, Bradley DG Microsatellite DNA variation and the evolution, domestication and phylogeography of taurine and zebu cattle (Bos taurus and Bos indicus). Genetics 1997, 146(3):1071-1086.

43. Heaton MP, Grosse WM, Kappes SM, Keele JW, Chitko-McKown CG, Cundiff LV, Braun A, Little DP, Laegreid WW: Estimation of DNA sequence diversity in bovine cytokine genes. Mamm Genome 2001, 12(1):32-37.

44. Taylor KH, Taylor JF, White SN, Womack JE: Identification of genetic variation and putative regulatory regions in bovine CARD15. Mamm Genome 2006, 17(8):892-901.

45. Cezar GG, Bartolomei MS, Forsberg EJ, First NL, Bishop MD, Eilertsen KJ: Genome-wide epigenetic alterations in cloned bovine fetuses. Biol Reprod 2003, 68(3):1009-1014

46. Rivera RM, Stein P, Weaver JR, Mager J, Schultz RM, Bartolomei MS: Manipulations of mouse embryos prior to implantation result in aberrant expression of imprinted genes on day 9.5 of development. Hum Mol Genet 2008, 17(1):1-14.

47. Takai D, Gonzales FA, Tsai YC, Thayer MJ, Jones PA: Large scale mapping of methylcytosines in CTCF-binding sites in the human H19 promoter and aberrant hypomethylation in human bladder cancer. Hum Mol Genet 2001, 10(23):2619-2626.

48. Beatty L, Weksberg R, Sadowski PD: Detailed analysis of the methylation patterns of the KvDMR1 imprinting control region of human chromosome 11. Genomics 2006, 87(1):46-56.

49. Cerrato F, Sparago A, Verde G, De Crescenzo A, Citro V, Cubellis MV, Rinaldi MM, Boccuto L, Neri G, Magnani C, et al: Different mechanisms cause imprinting defects at the IGF2/H19 locus in Beckwith-Wiedemann syndrome and Wilms' tumour. Hum Mol Genet 2008, 17(10):1427-1435.

50. Ideraabdullah FY, Vigneau S, Bartolomei MS: Genomic imprinting mechanisms in mammals. Mutat Res 2008, 647(1-2):77-85.

51. Qian N, Frank D, O'Keefe D, Dao D, Zhao L, Yuan L, Wang Q, Keating M, Walsh C, Tycko B: The IPL gene on chromosome 11p15.5 is imprinted in humans and mice and is similar to TDAG51, implicated in Fas expression and apoptosis. Hum Mol Genet 1997, 6(12):2021-2029.
52. Paulsen M, El-Maarri O, Engemann S, Strodicke M, Franck O, Davies K, Reinhardt $R$, Reik W, Walter J: Sequence conservation and variability of imprinting in the Beckwith-Wiedemann syndrome gene cluster in human and mouse. Hum Mol Genet 2000, 9(12):1829-1841.

53. Weber M, Milligan L, Delalbre A, Antoine E, Brunel C, Cathala G, Forne T: Extensive tissue-specific variation of allelic methylation in the lgf2 gene during mouse fetal development: relation to expression and imprinting. Mech Dev 2001, 101(1-2):133-141.

54. Mancini-DiNardo D, Steele SJ, Ingram RS, Tilghman SM: A differentially methylated region within the gene Kcnq1 functions as an imprinted promoter and silencer. Hum Mol Genet 2003, 12(3):283-294.

55. Gabory A, Ripoche MA, Yoshimizu T, Dandolo L: The H19 gene: regulation and function of a non-coding RNA. Cytogenet Genome Res 2006, 113(1-4):188-193.

56. Lewis A, Green K, Dawson C, Redrup L, Huynh KD, Lee JT, Hemberger M, Reik W: Epigenetic dynamics of the Kcnq1 imprinted domain in the early embryo. Development 2006, 133(21):4203-4210.

57. Caspary T, Cleary MA, Perlman EJ, Zhang P, Elledge SJ, Tilghman SM: Oppositely imprinted genes p57(Kip2) and igf2 interact in a mouse model for BeckwithWiedemann syndrome. Genes Dev 1999, 13(23):3115-3124.

58. Weksberg R, Shen DR, Fei YL, Song QL, Squire J: Disruption of insulin-like growth factor 2 imprinting in Beckwith-Wiedemann syndrome. Nat Genet 1993, 5(2):143-150.

59. Kalscheuer VM, Mariman EC, Schepens MT, Rehder $\mathrm{H}$, Ropers $\mathrm{HH}$ : The insulin-like growth factor type-2 receptor gene is imprinted in the mouse but not in humans. Nat Genet 1993, 5(1):74-78

60. Xu Y, Goodyer CG, Deal C, Polychronakos C: Functional polymorphism in the parental imprinting of the human IGF2R gene. Biochem Biophys Res Commun 1993, 197(2):747-754

61. Mizuno Y, Sotomaru Y, Katsuzawa Y, Kono T, Meguro M, Oshimura M, Kawai J, Tomaru Y, Kiyosawa H, Nikaido I, et al: Asb4, Ata3, and Den are novel imprinted genes identified by high-throughput screening using RIKEN cDNA microarray. Biochem Biophys Res Commun 2002, 290(5):1499-1505.

62. Sandell LL, Guan XJ, Ingram R, Tilghman SM: Gatm, a creatine synthesis enzyme, is imprinted in mouse placenta. Proc Natl Acad Sci USA 2003, 100 (8):4622-4627.

63. Monk D, Arnaud P, Apostolidou S, Hills FA, Kelsey G, Stanier P, Feil R, Moore GE: Limited evolutionary conservation of imprinting in the human placenta. Proc Natl Acad Sci USA 2006, 103(17):6623-6628.

64. Miziara MN, Riggs PK, Amaral ME: Comparative analysis of noncoding sequences of orthologous bovine and human gene pairs. Genet Mol Res 2004, 3(4):465-473

65. Khatib H, Zaitoun I, Kim ES: Comparative analysis of sequence characteristics of imprinted genes in human, mouse, and cattle. Mamm Genome 2007, 18(6-7):538-547

66. Miller W, Rosenbloom K, Hardison RC, Hou M, Taylor J, Raney B, Burhans R, King DC, Baertsch R, Blankenberg D, et al: 28-way vertebrate alignment and conservation track in the UCSC Genome Browser. Genome Res 2007, 17 (12):1797-1808

67. Gicquel C, Gaston V, Mandelbaum J, Siffroi JP, Flahault A, Le Bouc Y: In vitro fertilization may increase the risk of Beckwith-Wiedemann syndrome related to the abnormal imprinting of the KCN1OT gene. Am J Hum Genet 2003, 72(5):1338-1341.

68. Maher ER, Brueton LA, Bowdin SC, Luharia A, Cooper W, Cole TR, Macdonald F, Sampson JR, Barratt CL, Reik W, et al: Beckwith-Wiedemann syndrome and assisted reproduction technology (ART). J Med Genet 2003, 40(1):62-64.

69. Halliday J, Oke K, Breheny S, Algar E, JA D: Beckwith-Wiedemann syndrome and IVF: a case-control study. Am J Hum Genet 2004, 75(3):526-528.

70. Sutcliffe AG, Peters C, Bowdin S, Temple K, Reardon W, Wilson L, Clayton-Smith J, Brueton LA, Bannister W, Maher ER: Assisted reproductive therapies and imprinting disorders-a preliminary British survey. Hum Reprod 2006, 21 (4):1009-1011.

71. Robbins KM, Wells KD, Geary T, O'Gorman C, MacNeil MD, Smith MF, Pohler K, Jinks E, Rivera RM: Establishment of a phenotypical model of adverse outcomes associated with assisted reproductive technologies. Biol Reprod 2010, 83:316

doi:10.1186/1423-0127-19-95

Cite this article as: Robbins et al:: Expression of KCNQ1OT1, CDKN1C, H19, and PLAGL1 and the methylation patterns at the KvDMR1 and H19/ IGF2 imprinting control regions is conserved between human and bovine. Journal of Biomedical Science 2012 19:95. 